\title{
Ozone, Nitrogen Dioxide, and PM2.5 Measurement at Three Urban Parks in Manila, Philippines using Portable Sensors
}

\author{
Maria Cecilia Galvez ${ }^{*}, 1,2$, Daniel Paulo Tipan ${ }^{1}$, Angelo Ashtin Valera ${ }^{1}$, Edgar Vallar ${ }^{1,2}$, Alma Nacua ${ }^{3}$ \\ ${ }^{1}$ Environment And RemoTe sensing researcH (EARTH) Laboratory, Physics Department, De La Salle University, 2401 Taft Avenue, \\ Malate, Manila, 0922, Philippines
}

${ }^{2}$ Applied Research for Community, Health and Environment Resilience and Sustainability (ARCHERS), Center Natural Sciences and Environmental Research (CENSER), De La Salle University, 2401 Taft Avenue, Malate, Manila, 0922, Philippines

${ }^{3}$ Universidad de Manila, Cecilia Muñoz St., Ermita, Manila, 0922, Philippines

\begin{tabular}{l} 
A R T I C L E I N F O \\
\hline Article history: \\
Received: 29 July, 2020 \\
Accepted: 18 November, 2020 \\
Online: 14 December, 2020
\end{tabular}

Keywords:

Air Quality

Portable Sensors

Urban Parks

\begin{abstract}
A B S T R A C T
The presence of urban parks and green spaces in the city can play a role in maintaining urban residents' quality of life. Parks in Manila are located near main thoroughfares. Since people usually go to parks for recreation and relaxation it is important to have an idea of the concentration of criteria pollutants at these parks as they have great effects on people's health. Using portable sensors, one-hour average ambient concentration of $\mathrm{O}_{3}$, $\mathrm{NO}_{2}$, and $\mathrm{PM}_{2.5}$ was measured once a month between 8 am to 11 am local time from May 2018 to April 2019 at three popular urban parks in Manila, namely, Arroceros Forest Park, Rizal or Luneta Park, and Manila Zoo. Mean concentrations of $\mathrm{O}_{3}$ and $\mathrm{NO}_{2}$ are highest in Luneta Park at $0.071 \mathrm{ppm}$ and $0.032 \mathrm{ppm}$, respectively. In the case of PM 2.5 , the mean concentrations at Luneta and Arroceros Park are the same at $0.070 \mathrm{mg} / \mathrm{m}^{3}$. Manila Zoo had the lowest mean concentrations of the three criteria pollutants among the three urban parks. In terms of proximity to major thoroughfares, Luneta is closer and surrounded by four busy thoroughfares compared to Manila Zoo, and Arroceros Forest Park. It was also observed that measured concentrations of the three criteria pollutants were relatively higher during the cool dry months from October to February, with January 2019 recording the highest concentrations. Compared to a background site in Halang, Batangas, results of the measurement showed that the mean concentrations of $\mathrm{O}_{3}, \mathrm{NO}_{2}$, and $\mathrm{PM}_{2.5}$ at the three urban parks are higher demonstrating the effect of proximity of the parks to vehicular traffic on the air quality inside the parks.
\end{abstract}

\section{Introduction}

According to the State of Global Air Report 2019, air pollution is the fifth leading risk factor for mortality worldwide with the Philippines ranking number 10 in terms of the highest mortality burden attributable to air pollution [1]. Exposure to short-term and long-term air pollution is associated with respiratory and cardiovascular diseases [2]. In highly urbanized places like the National Capital Region (NCR) in the Philippines, popularly known as Metro Manila, air pollution aside from urban

${ }^{*}$ Corresponding Author: Maria Cecilia D. Galvez, EARTH Lab, Physics Dept. De La Salle University, 2401 Taft Avenue, Malate, Manila, Philippines. Contact No.: +639163526517 Email: maria.cecilia.galvez@dlsu.edu.ph heating is one of the region's major challenges [3]. In the latest National Emissions Inventory by source conducted in 2015, 88\% of air pollution in Metro Manila comes from mobile sources, 10\% from stationary sources, and a mere $2 \%$ from area sources. The increase in the number of vehicles is attributable to the increase in population to cater to the transport needs of the people [4]. In Metro Manila alone, there was an average increase of $7.77 \%$ in vehicular registration the year 2016-2018 (NCA, 2018). One of the 16 highly urbanized cities (HUCs) in Metro Manila is the City of Manila, the capital of the Philippines. It was the most densely populated among the HUCs with 71,263 persons per square kilometer in 2015 [5]. Criteria pollutants such as Nitrogen Dioxide 


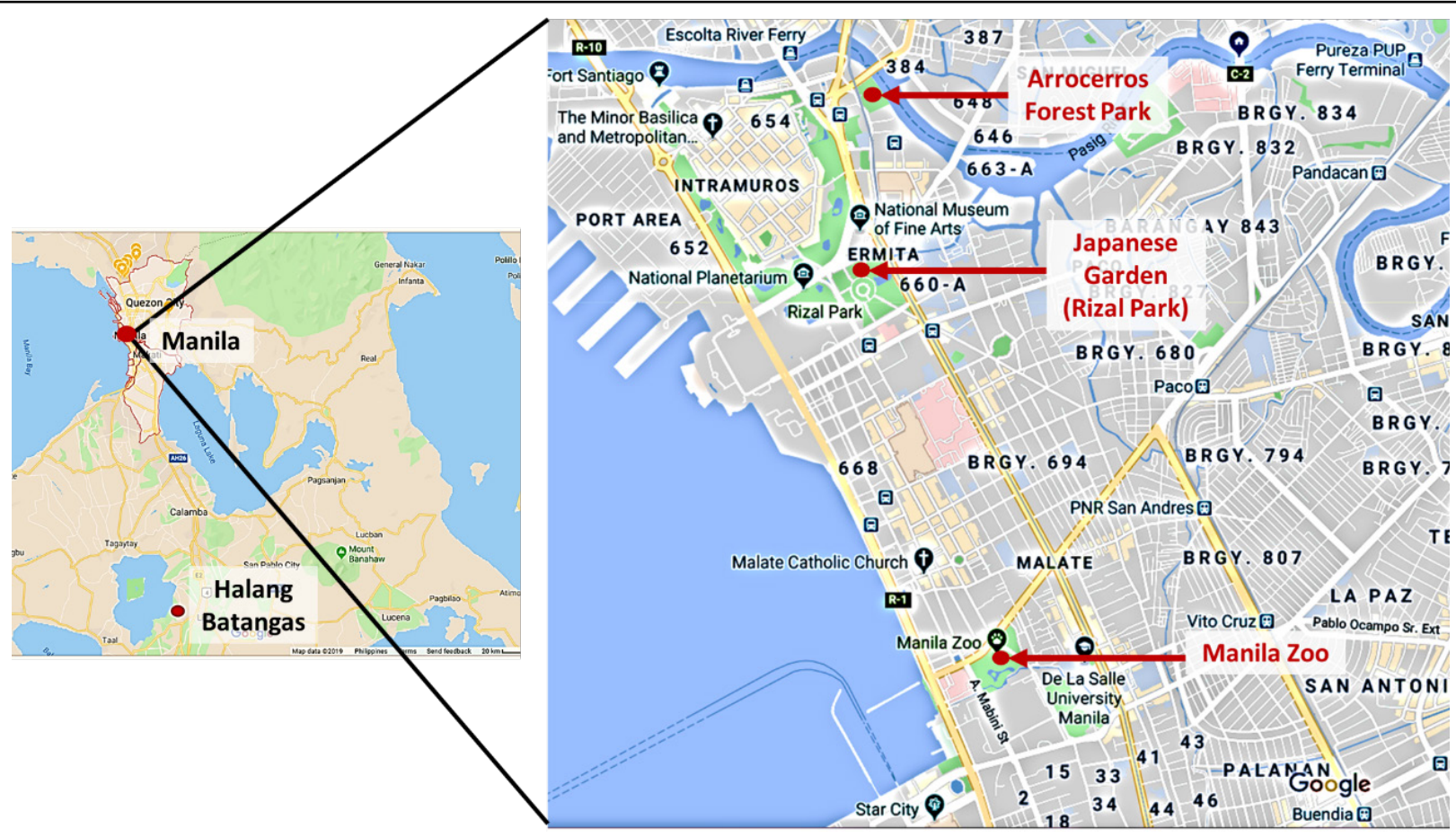

Figure 1: The location of the sampling sites relative to each other. Yellow and white lines indicate roads for vehicular traffic

Table 1: Location, coordinates, and addresses of the sampling sites

\begin{tabular}{|c|c|c|}
\hline Location & Coordinates & Address \\
\hline $\begin{array}{c}\text { Halang } \\
\text { (Background site) }\end{array}$ & $\begin{array}{l}13^{\circ} 57^{\prime} 26.9^{\prime \prime} \mathrm{N} \\
121^{\circ} 04^{\prime} 55.8^{\prime \prime} \mathrm{E}\end{array}$ & Halang, Lipa City, Batangas \\
\hline Arroceros Forest Park & $\begin{array}{l}13^{\circ} 57^{\prime} 26.9^{\prime \prime} \mathrm{N} \\
121^{\circ} 04^{\prime} 55.8^{\prime \prime} \mathrm{E}\end{array}$ & $\begin{array}{c}\text { Antonio Villegas St, } 659 \text { A Ermita, Manila, } 1000 \\
\text { Metro Manila }\end{array}$ \\
\hline $\begin{array}{l}\text { Japanese Garden } \\
\text { (in Luneta Park) }\end{array}$ & $\begin{array}{l}14^{\circ} 35^{\prime} 3^{\prime \prime} \mathrm{N} \\
120^{\circ} 58^{\prime} 44^{\prime \prime} \mathrm{E}\end{array}$ & $\begin{array}{c}\text { Maria Orosa Street corner Padre Burgos Street, } \\
\text { Manila, Metro Manila 1004, Philippines }\end{array}$ \\
\hline $\begin{array}{l}\text { Manila Zoological and } \\
\text { Botanical Garden }\end{array}$ & $\begin{array}{l}14^{\circ} 33^{\prime} 50^{\prime \prime} \mathrm{N} \\
120^{\circ} 59^{\prime} 18^{\prime \prime} \mathrm{E}\end{array}$ & $\begin{array}{c}\text { Adriatico St, Malate, Manila, } 1004 \\
\text { Metro Manila }\end{array}$ \\
\hline
\end{tabular}

Table 2: Summary of the sampling dates for each site

\begin{tabular}{|c|c|c|c|c|c|c|c|c|c|c|c|c|}
\hline Site & $\begin{array}{l}\text { May } \\
2018\end{array}$ & $\begin{array}{c}\text { Jun } \\
2018\end{array}$ & $\begin{array}{l}\text { July } \\
2018\end{array}$ & $\begin{array}{l}\text { Aug } \\
2018\end{array}$ & $\begin{array}{l}\text { Sept } \\
2018\end{array}$ & $\begin{array}{c}\text { Oct } \\
2018\end{array}$ & $\begin{array}{l}\text { Nov } \\
2018 \\
\end{array}$ & $\begin{array}{c}\text { Dec } \\
2018 \\
\end{array}$ & $\begin{array}{c}\text { Jan } \\
2019 \\
\end{array}$ & $\begin{array}{c}\text { Feb } \\
2019\end{array}$ & $\begin{array}{l}\text { Mar } \\
2019 \\
\end{array}$ & $\begin{array}{l}\text { Apr } \\
2019 \\
\end{array}$ \\
\hline Halang & 13 & 17 & 15 & 19 & 23 & 28 & 30 & 16 & 27 & 25 & 17 & 14 \\
\hline Arroceros & 17 & 27 & 19 & 24 & 27 & 22 & 21 & 14 & 31 & 27 & 20 & 29 \\
\hline Luneta & 18 & 25 & 30 & 29 & 26 & 24 & 23 & 13 & 30 & 28 & 21 & 11 \\
\hline Mla Zoo & 25 & 16 & 31 & 30 & 25 & 23 & 22 & 12 & 24 & 26 & 27 & 30 \\
\hline
\end{tabular}

$\left(\mathrm{NO}_{2}\right)$, Ozone $\left(\mathrm{O}_{3}\right)$, and fine particulate matter $\left(\mathrm{PM}_{2.5}\right)$ mostly come from mobile sources [4].

The increasing population and vehicles make Manila an example of unsustainable urbanization [6]. Hence, the presence of urban parks and green spaces in the city can play a role in maintaining urban residents' quality of life. Urban green space, a category of land cover that includes public parks and other (public or private) vegetated areas in densely populated places plays a great role in improving not only human health and but also the air quality [7-11]. To date, there were no available data on the level of air pollution in urban parks in Manila. People come to public parks to exercise, sometimes have family picnics, and just for relaxation. Some urban poor and street-dwellers make parks as their temporary home. Measurement of air pollution level is important especially if the parks are located or surrounded by main thoroughfares where traffic congestions are always present. These can increase the potential of park users to be exposed to pollutants associated with vehicular emissions. Lam et al made a study in Hongkong urban parks, and they have shown that the air quality in urban parks is better compared to the roadside but not significantly different from that in the ambient conditions [12]. Three of the popular parks in Metro Manila are located within the City of Manila. These are Manila Zoo, Luneta or Rizal Park, and 
Arroceros Forest Park. These three parks are located near the main thoroughfares, hence the proximity to vehicular traffic, which is the main source of air pollution in the city. There have been no air quality measurements in these parks as most static reference standard instruments are usually positioned near the roadside. The use of low-cost and portable air quality monitoring systems has become very popular as there is a need to provide a more accurate assessment of human air pollution exposure assessments [13]. In this study, the ambient concentrations of criteria pollutants such as nitrogen dioxide $\left(\mathrm{NO}_{2}\right)$, fine particulate $\left(\mathrm{PM}_{2.5}\right)$, and ozone $\left(\mathrm{O}_{3}\right)$ at these three public parks were measured once a month for one year using portable sensors. The measured ambient concentrations at the three parks are then compared to a background site in Halang, Batangas which is far from any vehicular traffic. The comparison between the urban parks and the background site will demonstrate the effect of vehicular traffic on the ambient concentrations of $\mathrm{PM}_{2.5}, \mathrm{NO}_{2}$, and $\mathrm{O}_{3}$. Furthermore, this study will explore the usefulness of portable sensors to provide real-time determination and assessment of air quality in public areas so that people will know the quality of the air they are breathing and, once the air quality drops to unhealthy levels, people can be requested to vacate the area. This will also provide information to authorities if there is a need to place static reference standard air quality monitoring system in such public areas.

\section{Materials and Methods}

\subsection{Sampling Sites}

The study was conducted at the three urban parks located in the city of Manila. These are Arroceros Forest Park, Luneta or Rizal Park, and Manila Zoo. For comparison, a background sampling site was included, and this was located in Halang, Batangas which is about $70 \mathrm{~km}$ south of Manila. The location and addresses of the sampling sites are given in Table 1 and Figure1 shows the relative location of each sampling site. Yellow and white lines indicate roads for vehicular traffic. Permits were secured with the park administrators for us to conduct the measurements, which should be done only during office hours. Sampling Site 1 is the Arroceros Forest Park (AFP), also called as the "Last Lung of Manila". It is a 2.2-hectare (5.4-acre) manmade urban forest along Pasig River, at the foot of Quezon Bridge. The second sampling site is Rizal Park also known as Luneta Park or simply Luneta is a historical urban park in the Philippines and one of the major tourist attractions of Manila. It is approximately 16.24 hectares (40.01) acre and located along Roxas Boulevard, Manila, and also adjacent to Taft Avenue, Manila. The last urban park is the Manila Zoological and Botanical Garden or Manila Zoo. It is a 5.5-hectare (14-acre) zoo located in Malate, Manila, Philippines.

\subsection{Measurement}

The criteria pollutants measured in this study are $\mathrm{PM}_{2.5}, \mathrm{NO}_{2}$, and $\mathrm{O}_{3}$. A DustTrak ${ }^{\mathrm{TM}} \mathrm{DRX}$ aerosol monitor (Model 8533, TSI incorporated) that used a light scattering technique to infer the mass concentration of particles was used for $\mathrm{PM}_{2.5}$ measurement [14]. It was set on a 1 -s time resolution at $3 \mathrm{~L} /$ minutes. Before the start of each measurement, zero calibration was performed using a TSI 800663 zero filter. $\mathrm{NO}_{2}$ and $\mathrm{O}_{3}$ concentrations were measured by a real-time portable battery-operated gas sensor monitor AEROQUAL Series 500 with $\mathrm{NO}_{2}$ and $\mathrm{O}_{3}$ sensor heads. The sensor heads used gas-sensitive electrochemical (GSE) technology www.astesj.com where it measures the concentration of a target gas by using oxidation or reduction reactions to generate a positive or negative current flow through an external circuit and the magnitude of this current is proportional to the gas concentration. The operating parameters of the sensor heads are as follows; $\mathrm{O}_{3}$ (detection range $0-10 \mathrm{ppm}$; resolution and minimum detection limits $0.01 \mathrm{ppm}$; response time $60 \mathrm{secs}$; temperature $0-40^{\circ} \mathrm{C}$; relative humidity 15 - 90\%), $\mathrm{NO}_{2}$ (detection range $0-1 \mathrm{ppm}$; resolution $0.001 \mathrm{ppm}$; minimum detection limits $0.005 \mathrm{ppm}$; response time 30 secs; temperature $0-40^{\circ} \mathrm{C}$; relative humidity $15-90 \%$ ). A 1-min time resolution was used during the measurement. Although the DustTrak and Aeroqual are not regulatory-grade monitors they are widely used in prior air quality research studies [13,15-24]. Measurements done for this paper were performed during the warranty period of the instruments. Being under warranty, instrument calibration and performance was within factory specifications. During the measurements, researchers observed the performance of the instruments, and temperature and humidity on the site were within their specified operating conditions. Simultaneous measurement on all sampling sites was not possible because only one set of instruments was available. Background measurement in Halang, Batangas was done on a Sunday, and the measurements at the three parks in Manila were conducted on the following weekdays if weather permits. The sampling dates are summarized in Table 2. To observe the same atmospheric and vehicular traffic conditions in the site, measurements were done on successive days in the morning between 8 am to 11 am local time for one hour, once a month for each sampling site for one year. Measurement was not conducted during bad weather conditions and sampling time was chosen to also avoid the effect of sunlight on $\mathrm{O}_{3}$ concentration.

\section{Results}

One Way Analysis of Variance (ANOVA) was the statistical method used for identifying if there are any significant differences in the measured concentration of a particular criteria pollutant at the different sampling sites. If there's a significant difference, a Tukey honestly significant difference (HSD) test is then carried out to identify what sampling locations are significantly different, and then based on the mean concentration, the locations are ranked from highest to lowest concentration. RealStat (http://www.realstatistics.com/) Microsoft Excel Add-In was used to carry out the statistical calculation. An alpha value of 0.01 was used. To illustrate the variation of air pollution concentrations at each sampling site, Box and Whisker plots were used in terms of the lower quartile, upper quartile, median, mean, minimum, and maximum in each of the four study locations.

\subsection{Ozone $\left(\mathrm{O}_{3}\right)$ Measurement}

Shown in Figure 2 is the box plot of the $\mathrm{O}_{3}$ concentrations from the four different locations from May 2018 to April 2019. Table $3 \mathrm{a}$ shows the result of the statistical analysis for $\mathrm{O}_{3}$. In all the sampling months, there was a significant difference in $\mathrm{O}_{3}$ concentration between each sampling site. The $\mathrm{O}_{3}$ concentrations at the background site always have the lowest concentration on all sampling months. The DENR EMB National Ambient Air Quality Guideline Values (NAAQGV) for 1-Hour Averaging is 0.07 ppm [4], [25]. As shown in Figure 3, in some months, the measured $\mathrm{O}_{3}$ concentration was $0 \mathrm{ppm}$ at the background site 
Table 3: One way Anova P-value between each sampling sites per month for (a) Ozone, (b) Nitrogen Dioxide, (c) PM $_{2.5}$.

(a) Ozone (in ppm)

\begin{tabular}{|c|c|c|c|}
\hline Month & $P$ value & Location & Mean \\
\hline \multirow{3}{*}{ May 2018} & \multirow{3}{*}{$7.52 \mathrm{E}-05$} & Arroceros & 0.067 \\
\hline & & Batangas & 0.045 \\
\hline & & Luneta & 0.041 \\
\hline \multirow{4}{*}{ June 2018} & \multirow{4}{*}{$7.35 \mathrm{E}-37$} & Arroceros & 0.063 \\
\hline & & Batangas & 0.041 \\
\hline & & Luneta & 0.082 \\
\hline & & Manila Zoo & 0.056 \\
\hline \multirow{4}{*}{ July 2018} & \multirow{4}{*}{ 4.61E-31 } & Arroceros & 0.061 \\
\hline & & Batangas & 0.040 \\
\hline & & Luneta & 0.049 \\
\hline & & Manila Zoo & 0.049 \\
\hline \multirow{3}{*}{ August 2018} & \multirow{3}{*}{$5.06 \mathrm{E}-05$} & Arroceros & 0.060 \\
\hline & & Batangas & 0.046 \\
\hline & & Manila Zoo & 0.054 \\
\hline \multirow{4}{*}{ September 2018} & \multirow{4}{*}{$4.18 \mathrm{E}-33$} & Arroceros & 0.078 \\
\hline & & Batangas & 0.047 \\
\hline & & Luneta & 0.064 \\
\hline & & Manila Zoo & 0.063 \\
\hline \multirow{4}{*}{ October 2018} & \multirow{4}{*}{$2.45 E-38$} & Arroceros & 0.081 \\
\hline & & Batangas & 0.057 \\
\hline & & Luneta & 0.085 \\
\hline & & Manila Zoo & 0.069 \\
\hline \multirow{4}{*}{ November 2018} & \multirow{4}{*}{ 4.06E-79 } & Arroceros & 0.060 \\
\hline & & Batangas & 0.052 \\
\hline & & Luneta & 0.089 \\
\hline & & Manila Zoo & 0.056 \\
\hline \multirow{4}{*}{ December 2018} & \multirow{4}{*}{ 4.34E-15 } & Arroceros & 0.061 \\
\hline & & Batangas & 0.053 \\
\hline & & Luneta & 0.067 \\
\hline & & Manila Zoo & 0.054 \\
\hline \multirow{4}{*}{ January 2019} & \multirow{4}{*}{$6.59 E-37$} & Arroceros & 0.078 \\
\hline & & Batangas & 0.062 \\
\hline & & Luneta & 0.082 \\
\hline & & Manila Zoo & 0.074 \\
\hline \multirow{4}{*}{ February 2019} & \multirow{4}{*}{$1.86 \mathrm{E}-24$} & Arroceros & 0.066 \\
\hline & & Batangas & 0.055 \\
\hline & & Luneta & 0.071 \\
\hline & & Manila Zoo & 0.067 \\
\hline \multirow{4}{*}{ March 2019} & \multirow{4}{*}{$4.58 \mathrm{E}-25$} & Arroceros & 0.064 \\
\hline & & Batangas & 0.048 \\
\hline & & Luneta & 0.058 \\
\hline & & Manila Zoo & 0.072 \\
\hline \multirow{4}{*}{ April 2019} & \multirow{4}{*}{$7.47 E-62$} & Arroceros & 0.066 \\
\hline & & Batangas & 0.047 \\
\hline & & Luneta & 0.076 \\
\hline & & Manila Zoo & 0.072 \\
\hline
\end{tabular}

(b) Nitrogen Dioxide (ppm)

\begin{tabular}{|c|c|c|c|}
\hline Month & $P$ value & Location & Mean \\
\hline \multirow{4}{*}{ June 2018} & \multirow{4}{*}{$1.51 \mathrm{E}-13$} & Arroceros & 0.024 \\
\hline & & Batangas & 0.018 \\
\hline & & Luneta & 0.040 \\
\hline & & Manila Zoo & 0.012 \\
\hline \multirow{4}{*}{ July 2018} & \multirow{4}{*}{$8.28 \mathrm{E}-05$} & Arroceros & 0.011 \\
\hline & & Batangas & 0.007 \\
\hline & & Luneta & 0.012 \\
\hline & & Manila Zoo & 0.003 \\
\hline \multirow{3}{*}{ August 2018} & \multirow{3}{*}{0.053493} & Arroceros & 0.015 \\
\hline & & Batangas & 0.013 \\
\hline & & Manila Zoo & 0.020 \\
\hline \multirow{4}{*}{ September 2018} & \multirow{4}{*}{$7.4 \mathrm{E}-11$} & Arroceros & 0.021 \\
\hline & & Batangas & 0.008 \\
\hline & & Luneta & 0.021 \\
\hline & & Manila Zoo & 0.005 \\
\hline \multirow{4}{*}{ October 2018} & \multirow{4}{*}{$6.7 \mathrm{E}-33$} & Arroceros & 0.028 \\
\hline & & Batangas & 0.016 \\
\hline & & Luneta & 0.040 \\
\hline & & Manila Zoo & 0.013 \\
\hline \multirow{4}{*}{ November 2018} & \multirow{4}{*}{$2.84 \mathrm{E}-51$} & Arroceros & 0.022 \\
\hline & & Batangas & 0.008 \\
\hline & & Luneta & 0.047 \\
\hline & & Manila Zoo & 0.004 \\
\hline \multirow{4}{*}{ December 2018} & \multirow{4}{*}{$4.24 \mathrm{E}-14$} & Arroceros & 0.010 \\
\hline & & Batangas & 0.016 \\
\hline & & Luneta & 0.028 \\
\hline & & Manila Zoo & 0.034 \\
\hline \multirow{4}{*}{ January 2019} & \multirow{4}{*}{$2.32 \mathrm{E}-29$} & Arroceros & 0.039 \\
\hline & & Batangas & 0.026 \\
\hline & & Luneta & 0.061 \\
\hline & & Manila Zoo & 0.034 \\
\hline \multirow{4}{*}{ February 2019} & \multirow{4}{*}{$5.42 \mathrm{E}-28$} & Arroceros & 0.042 \\
\hline & & Batangas & 0.013 \\
\hline & & Luneta & 0.040 \\
\hline & & Manila Zoo & 0.042 \\
\hline \multirow{4}{*}{ March 2019} & \multirow{4}{*}{$6.1 \mathrm{E}-13$} & Arroceros & 0.035 \\
\hline & & Batangas & 0.016 \\
\hline & & Luneta & 0.031 \\
\hline & & Manila Zoo & 0.034 \\
\hline \multirow{4}{*}{ April 2019} & \multirow{4}{*}{$2.52 \mathrm{E}-19$} & Arroceros & 0.023 \\
\hline & & Batangas & 0.037 \\
\hline & & Luneta & 0.047 \\
\hline & & Manila Zoo & 0.029 \\
\hline
\end{tabular}

(c) $\mathrm{PM}_{2.5}\left(\mathrm{mg} / \mathrm{m}^{3}\right)$

\begin{tabular}{|c|c|c|c|}
\hline Month & P value & Location & Mean \\
\hline \multirow{4}{*}{ May 2018} & \multirow{4}{*}{ 1.79E-79 } & Batangas & 0.017 \\
\hline & & Arroceros & 0.074 \\
\hline & & Luneta & 0.033 \\
\hline & & Manila Zoo & 0.086 \\
\hline \multirow{4}{*}{ June 2018} & \multirow{4}{*}{$2.09 \mathrm{E}-152$} & Batangas & 0.023 \\
\hline & & Arroceros & 0.044 \\
\hline & & Luneta & 0.117 \\
\hline & & Manila Zoo & 0.055 \\
\hline \multirow{4}{*}{ July 2018} & \multirow{4}{*}{ 4.26E-95 } & Batangas & 0.002 \\
\hline & & Arroceros & 0.104 \\
\hline & & Luneta & 0.028 \\
\hline & & Manila Zoo & 0.033 \\
\hline \multirow{4}{*}{ August 2018} & \multirow{4}{*}{$4.08 \mathrm{E}-138$} & Batangas & 0.039 \\
\hline & & Arroceros & 0.113 \\
\hline & & Luneta & 0.044 \\
\hline & & Manila Zoo & 0.054 \\
\hline \multirow{4}{*}{ September 2018} & \multirow{4}{*}{$3.16 \mathrm{E}-214$} & Batangas & 0.023 \\
\hline & & Arroceros & 0.088 \\
\hline & & Luneta & 0.036 \\
\hline & & Manila Zoo & 0.077 \\
\hline \multirow{4}{*}{ October 2018} & \multirow{4}{*}{$1.62 \mathrm{E}-43$} & Batangas. & 0.043 \\
\hline & & Arroceros & 0.071 \\
\hline & & Luneta & 0.077 \\
\hline & & Manila Zoo & 0.048 \\
\hline \multirow{4}{*}{ November 2018} & \multirow{4}{*}{ 3.47E-112 } & Batangas & 0.018 \\
\hline & & Arroceros & 0.040 \\
\hline & & Luneta & 0.077 \\
\hline & & Manila Zoo & 0.059 \\
\hline \multirow{4}{*}{ December 2018} & \multirow{4}{*}{$2.61 \mathrm{E}-157$} & Batangas & 0.014 \\
\hline & & Arroceros & 0.040 \\
\hline & & Luneta & 0.077 \\
\hline & & Manila Zoo & 0.024 \\
\hline \multirow{4}{*}{ January 2019} & \multirow{4}{*}{ 2.23E-135 } & Batangas & 0.029 \\
\hline & & Arroceros & 0.112 \\
\hline & & Luneta & 0.107 \\
\hline & & Manila Zoo & 0.079 \\
\hline \multirow{4}{*}{ February 2019} & \multirow{4}{*}{$5.06 \mathrm{E}-118$} & Batangas & 0.045 \\
\hline & & Arroceros & 0.026 \\
\hline & & Luneta & 0.086 \\
\hline & & Manila Zoo & 0.071 \\
\hline \multirow{4}{*}{ March 2019} & \multirow{4}{*}{ 5.87E-67 } & Batangas & 0.026 \\
\hline & & Arroceros & 0.046 \\
\hline & & Luneta & 0.032 \\
\hline & & Manila Zoo & 0.077 \\
\hline \multirow{4}{*}{ April 2019} & & Batangas & 0.027 \\
\hline & & Arroceros & 0.073 \\
\hline & $1.4 / \mathrm{E}-133$ & Luneta & 0.079 \\
\hline & & Manila Zoo & 0.047 \\
\hline
\end{tabular}

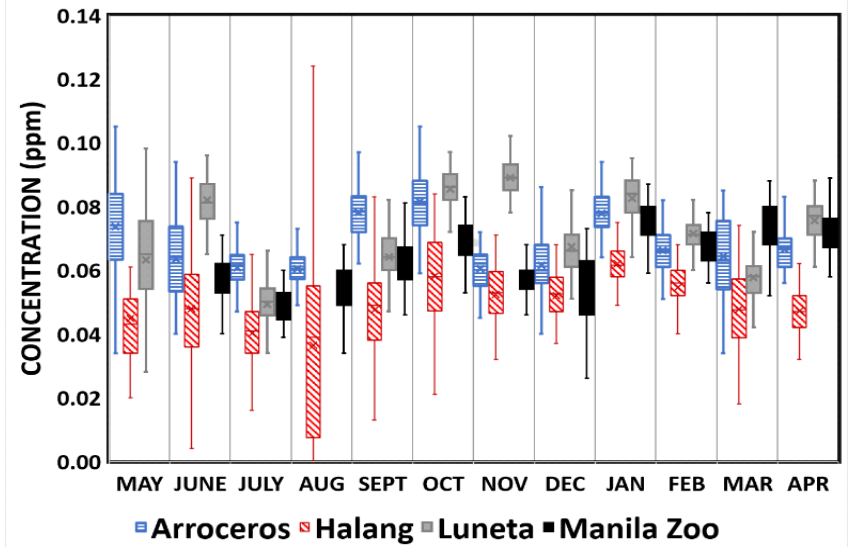

Figure 2: Box plot of monthly concentration of $\mathrm{O}_{3}$ at the four sampling sites from May 2018-April 2019

For the whole year, as shown in Figure 3, Luneta had the highest concentration of $0.071 \mathrm{ppm}$ and Arroceros was a close second at $0.067 \mathrm{ppm}$, followed by Manila Zoo at 0.063 $\underline{\text { www.astesj.com }}$ ppm, and the background site at $0.050 \mathrm{ppm}$. A high concentration of $\mathrm{O}_{3}$ exceeding the NAAQGV was observed for all sites except the background site in January 2019 which is one of the coldest months in the Philippines.

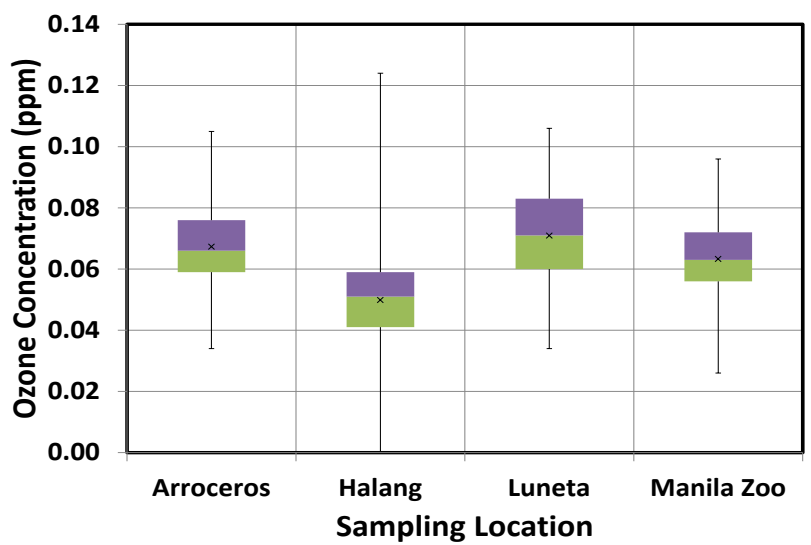

Figure 3: Box plot of the one year mean $\mathrm{O} 3$ concentration at the four sampling sites from May 2018-April 2019. 


\subsection{Nitrogen Dioxide $\left(\mathrm{NO}_{2}\right)$ Measurement}

Shown in Figure 4 is the box plot of the $\mathrm{NO}_{2}$ concentration from the four different locations from May 2018 to April 2019. Table $3 \mathrm{~b}$ shows the result of the statistical analysis. In all the sampling months, there was a significant difference in $\mathrm{NO}_{2}$ concentration between each sampling site. The $\mathrm{NO}_{2}$ concentrations at the background site have the lowest concentration on all sampling months. On some months, the $\mathrm{NO}_{2}$ concentration was 0 ppm indicating that the $\mathrm{NO}_{2}$ concentration was below the detection limit of the $\mathrm{NO}_{2}$ sensor. This was true most especially in the case of the background site where the lower quartile value was equal to the minimum value measured by the $\mathrm{NO}_{2}$ sensor. For the whole year, as shown in Figure 5, there is a significant difference in all sampling locations. Luneta having the highest concentration of $0.032 \mathrm{ppm}$ and Arroceros is a close second at $0.025 \mathrm{ppm}$, followed by Manila Zoo at $0.022 \mathrm{ppm}$ and the background site at 0.017 ppm.. The National guideline value for $\mathrm{NO}_{2}$ is $150 \mu \mathrm{g} / \mathrm{Ncm}(0.08$ ppm) maximum for a 24-hour exposure [25]. As in the case of $\mathrm{O}_{3}$, the coldest month of January and February 2019 registered higher $\mathrm{NO}_{2}$ concentrations for all the urban parks except the background site.

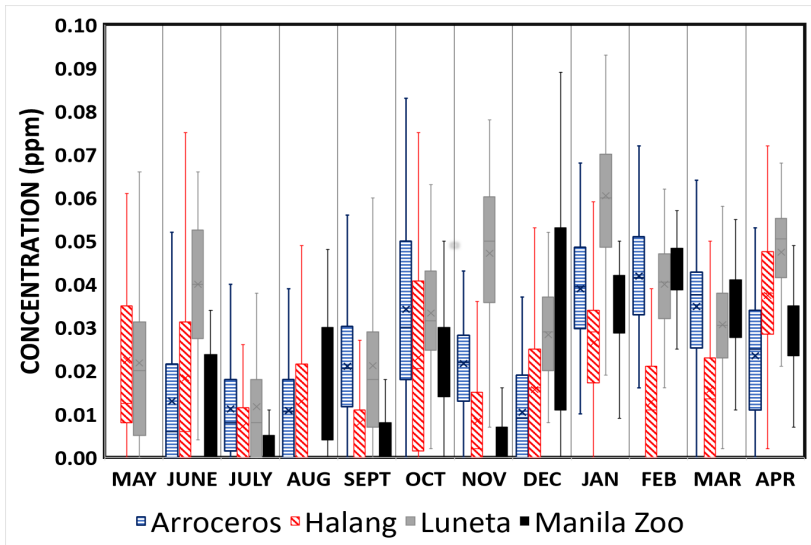

Figure 4: Box plot of monthly concentration of $\mathrm{NO} 2$ at the four sampling sites from May 2018-April 2019.

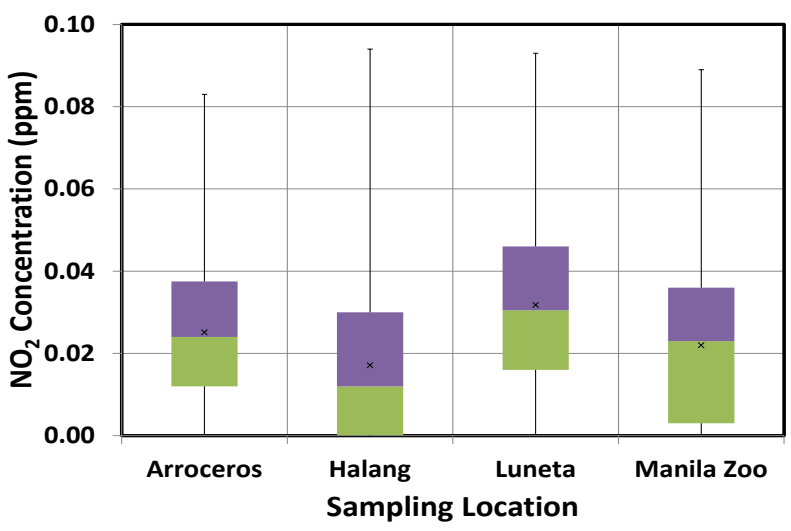

Figure 5: Box plot of the one year mean $\mathrm{NO}_{2}$ concentration at the four sampling sites from May 2018-April 2019.

For Particulate Matter measurement, TSI DUSTTRAK DRX Aerosol Monitor 8533 was used and this can measure $\mathrm{PM}_{10}, \mathrm{PM}_{2.5}$, and $\mathrm{PM}_{1.0}$ but only $\mathrm{PM}_{2.5}$ will be presented. For statistical analysis, only $\mathrm{PM}_{2.5}$ measurement will be used since all the other PM sizes www.astesj.com follow the same trend. Furthermore, in terms of Air Quality Guidelines, $\mathrm{PM}_{2.5}$ is the one that is reported. No air quality guidelines yet for $\mathrm{PM}_{1.0}$. Shown in Figure 6 are the box plots of the $\mathrm{PM}_{2.5}$ concentration measured by the DUSTTRAK. The lowest concentration of PM is in Halang, Batangas while Arroceros always gives the highest concentration. The result of One-way ANOVA indicates a significant difference in the PM concentration for all months between each sampling location. Arroceros always ranks the highest while Halang is the lowest. The WHO Air Quality Guideline values for $\mathrm{PM}_{2.5}$ is $10 \mu \mathrm{g} / \mathrm{m}^{3}$ annual mean and $0.025 \mathrm{mg} / \mathrm{m}^{3}$ 24-hour mean [4]. NAAQGV are $0.025 \mathrm{mg} / \mathrm{m}^{3}$ annual mean and $0.050 \mathrm{mg} / \mathrm{m}^{3}$ 24-hour mean [4]. It can be seen from Figure 7 that the $\mathrm{PM}_{2.5}$ concentration measured from TSI DUSTTRAK at the sampling locations in Manila exceeds the annual mean guideline values. However, please note that the instrument is not the reference instrument. Like $\mathrm{O}_{3}$ and $\mathrm{NO}_{2}$, it was also observed that in January 2019, high values of $\mathrm{PM}_{2.5}$ concentration were measured at the urban parks exceeding the 24-hour mean NAAQGV.

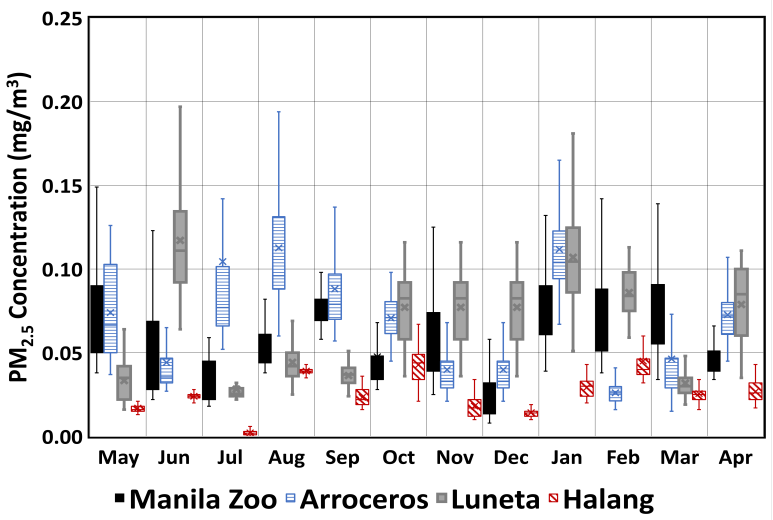

Figure 6: Box plot of monthly concentration of PM2.5 at the four sampling sites from May 2018-April 2019

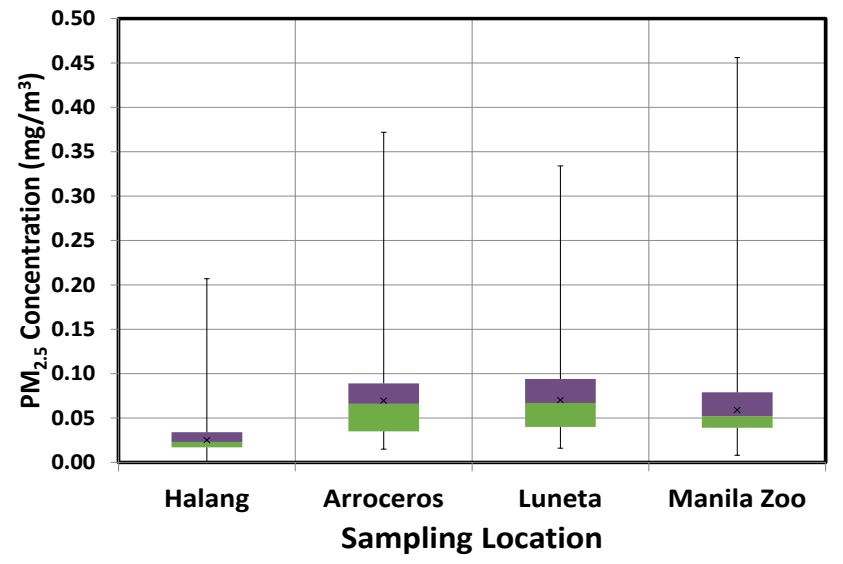

Figure 7: Box plot of the one year mean $\mathrm{PM}_{2.5}$ concentration at the four the four sampling sites from May 2018-April 2019

With the unsustainable urbanization in Manila, the presence of urban parks can provide residence with quality of life. However, the location of these parks affects the air quality within the park. The measured values of $\mathrm{O}_{3}, \mathrm{NO}_{2}$, and $\mathrm{PM}_{2.5}$ at the three well known urban parks in Manila are higher compared with a background site in Halang, Batangas. Using portable sensors, the 
ambient concentration of $\mathrm{O}_{3}, \mathrm{NO}_{2}$, and $\mathrm{PM}_{2.5}$ was measured once a month between 8 am to 11 am local time from May 2018 to April 2019 at three known urban parks in Manila, namely, Arroceros Forest Park, Rizal or Luneta Park, and Manila Zoo. Mean concentrations of $\mathrm{O}_{3}$ and $\mathrm{NO}_{2}$ are highest in Luneta Park at 0.071 $\mathrm{ppm}$ and $0.032 \mathrm{ppm}$, respectively. Among the three parks, Luneta is the one surrounded by major roads. For mean concentration of $\mathrm{PM}_{2.5}$, Luneta, and Arroceros Park are the same at $0.070 \mathrm{mg} / \mathrm{m}^{3}$. One of the main reasons is the proximity of the three parks to vehicular traffic. It was also observed that measured concentrations of the three criteria pollutants were relatively higher during the cool dry months from October to February. Although the instruments used were not the reference instruments, the result provides information on the necessity of monitoring the air quality within the parks. Many residents most especially people who cannot afford, and don't have time to go out of the city need these urban parks for relaxation and recreational activities.

\section{Conflict of Interest}

The authors declare no conflict of interest.

\section{Acknowledgment}

The authors would like to acknowledge the support from Commission on Higher Education (CHED) project entitled UDM CHED DARETO "Using wireless environmental monitoring sensors in assessing the impact of megacity environmental pollution and local climate on butterfly diversity in Manila, Philippines" and CHED -Grant-In-Aid Project "Evaluation of Human Skin Analogues" and we also acknowledge ARCHERS, CENSER through EARTH lab and De La Salle University Research Coordination Office (URCO) 47 F U 2TAY18-2TAY19 for partially supporting this project.

\section{References}

[1] M.E.I. Health Effects Institute. 2019. State of Global Air 2019. Special Report. Boston, "A SPECIAL REPORT ON GLOBAL EXPOSURE TO AIR POLLUTION AND ITS DISEASE BURDEN What is the State of Global Air? Who is it for? How can I explore the data?," Boston, MA:Health Effects Institute., 24, 2019.

[2] B. Chen, H. Kan, "Air pollution and population health: A global challenge," Environmental Health and Preventive Medicine, 13(2), 94-101, 2008, doi:10.1007/s12199-007-0018-5.

[3] J. Oliveros, E. Vallar, M. Galvez, "Investigating the Effect of Urbanization on Weather Using the Weather Research and Forecasting (WRF) Model: A Case of Metro Manila, Philippines," Environments, 6(2), 10, 2019, doi:10.3390/environments6020010.

[4] Department of Environment and Natural Resources Philippines Environmental Management Bureau, "Air Quality in the Philippines (20082015)," 2016.

[5] Philippine Population Density (Based on the 2015 Census of Population) | Philippine Statistics Authority, Nov. 2019.

[6] S. Kecorius, L. Madueño, E. Vallar, H. Alas, G. Betito, W. Birmili, M.O. Cambaliza, G. Catipay, M. Gonzaga-Cayetano, M.C. Galvez, G. Lorenzo, T. Müller, J.B. Simpas, E.G. Tamayo, A. Wiedensohler, "Aerosol particle mixing state, refractory particle number size distributions and emission factors in a polluted urban environment: Case study of Metro Manila, Philippines," Atmospheric Environment, 170, 169-183, 2017, doi:10.1016/j.atmosenv.2017.09.037.

[7] C.R. Chang, M.H. Li, "Effects of urban parks on the local urban thermal environment," Urban Forestry and Urban Greening, 2014, doi:10.1016/j.ufug.2014.08.001.

[8] A. Chiesura, "The role of urban parks for the sustainable city," Landscape and Urban Planning, 2004, doi:10.1016/j.landurbplan.2003.08.003.
[9] B. Givoni, "Impact of planted areas on urban environmental quality: A review," Atmospheric Environment. Part B, Urban Atmosphere, 1991, doi:10.1016/0957-1272(91)90001-U.

[10] L.R. Larson, V. Jennings, S.A. Cloutier, "Public parks and wellbeing in urban areas of the United States," PLoS ONE, 2016, doi:10.1371/journal.pone.0153211.

[11] J. Vieira, P. Matos, T. Mexia, P. Silva, N. Lopes, C. Freitas, O. Correia, M. Santos-Reis, C. Branquinho, P. Pinho, "Green spaces are not all the same for the provision of air purification and climate regulation services: The case of urban parks,” Environmental Research, 160(December 2016), 306-313, 2018, doi:10.1016/j.envres.2017.10.006.

[12] K.C. Lam, S.L. Ng, W.C. Hui, P.K. Chan, "Environmental quality of urban parks and open spaces in Hong Kong," Environmental Monitoring and Assessment, 2005, doi:10.1016/j.cccn.2005.02.014.

[13] G.R. McKercher, J.A. Salmond, J.K. Vanos, "Characteristics and applications of small, portable gaseous air pollution monitors," Environmental Pollution, 223, 102-110, 2017 doi:10.1016/j.envpol.2016.12.045.

[14] TSI, "DustTrak DRX Aerosol Monitors Models 8533, 8533EP And 8534," 2014, 4, 2014.

[15] K.N. Jallad, C. Espada-Jallad, "Characterization of Road Traffic Emissions in a Densely Populated Residential Area of Kuwait," Environment and Natural Resources Research, 2(2), 2-15, 2012, doi:10.5539/enrr.v2n2p2.

[16] I. Rivas, M. Mazaheri, M. Viana, T. Moreno, S. Clifford, C. He, O.F. Bischof, V. Martins, C. Reche, A. Alastuey, M. Alvarez-Pedrerol, J. Sunyer, L. Morawska, X. Querol, "Identification of technical problems affecting performance of DustTrak DRX aerosol monitors," Science of the Total Environment, $\quad \mathbf{5 8 4 - 5 8 5 ,} \quad 849-855, \quad 2017$, doi:10.1016/j.scitotenv.2017.01.129.

[17] M. Masiol, S. Squizzato, D. Chalupa, D.Q. Rich, P.K. Hopke, "Spatialtemporal variations of summertime ozone concentrations across a metropolitan area using a network of low-cost monitors to develop 24 hourly land-use regression models," Science of the Total Environment, 654, 1167 1178, 2019, doi:10.1016/j.scitotenv.2018.11.111.

[18] E. Ezani, N. Masey, J. Gillespie, T.K. Beattie, Z.K. Shipton, I.J. Beverland, "Measurement of diesel combustion-related air pollution downwind of an experimental unconventional natural gas operations site," Atmospheric Environment, 189(November 2017), 30-40, 2018, doi:10.1016/j.atmosenv.2018.06.032

[19] C. Lin, J. Gillespie, M.D. Schuder, W. Duberstein, I.J. Beverland, M.R. Heal, "Evaluation and calibration of Aeroqual series 500 portable gas sensors for accurate measurement of ambient ozone and nitrogen dioxide," Atmospheric Environment, 100(2), 111-116, 2015, doi:10.1016/j.atmosenv.2014.11.002.

[20] J.Y. Kim, S.R. Magari, R.F. Herrick, T.J. Smith, D.C. Christiani, "Comparison of fine particle measurements from a direct-reading instrument and a gravimetric sampling method," Journal of Occupational and Environmental Hygiene, 1(11), 707-715, 2004 doi:10.1080/15459620490515833.

[21] D. Liu, Q. Zhang, J. Jiang, D.R. Chen, "Performance calibration of low-cost and portable particular matter (PM) sensors," Journal of Aerosol Science, 2017, doi:10.1016/j.jaerosci.2017.05.011.

[22] J.D. Yanosky, P.L. Williams, D.L. MacIntosh, "A comparison of two directreading aerosol monitors with the federal reference method for PM2.5 in indoor air," Atmospheric Environment, 36(1), 107-113, 2002, doi:10.1016/S1352-2310(01)00422-8.

[23] S.E. Bartington, I. Bakolis, D. Devakumar, O.P. Kurmi, J. Gulliver, G. Chaube, D.S. Manandhar, N.M. Saville, A. Costello, D. Osrin, A.L. Hansell, J.G. Ayres, "Patterns of domestic exposure to carbon monoxide and particulate matter in households using biomass fuel in Janakpur, Nepal," $\begin{array}{llll}\text { Environmental } & \text { Pollution, } & \text { 220, } & 38-45,\end{array}$ doi:10.1016/j.envpol.2016.08.074.

[24] Z. Ali, K. Shahzadi, S. Sidra, Z. Zona, I. Zainab, K. Aziz, M. Ahmad, S.T Raza, Z.A. Nasir, I. Colbeck, "Seasonal variation of particulate matter in the ambient conditions of Khanspur, Pakistan," Journal of Animal and Plant Sciences, 25(3), 700-705, 2015

[25] Department of Environment and Natural Resources Philippines Environmental Management Bureau, "2002 National Air Quality Status Report," 2002. 